\title{
Interaction of cyanine dyes with nucleic acids. 4. Efficient 5'-fluorescent labelling of oligonucleotides with monomethyne pyrylium cyanine dye, Cyan 39
}

\author{
Sergiy M. Yarmoluk, Alexander M. Kostenko, Olga S. Kornushyna, Igor Y. Dubey ${ }^{1}$ \\ Institute of Molecular Biology and Gentetics, National Academy of Sciences of Ukraine \\ 150 Zabololnogo str., 252143, Kyiv, Likraine \\ 1 \\ Institute of Bioorganic Chemistry and Petruchemistry, National Academy of Sciences of Ukraine \\ 1 Murmanska str., 253660, Kyiv, Ukraine
}

A ni'w system for fluorescent 5 -end labelling of oligonucieotides with cyanine dyes is proposed. Reaction of primary amine with pyrylium salt was used for the efficient conjugation of monomethyne pyrylium cyanine dye with 5 -amincalkyl oligonucleotide with simultaneous conversion of the "brightless pyrylium dye Cyan 39 into "bright" pyridinium one Cyan 40.

Introduction. Oligonucleotides labelled with fluorescent reporter groups are widely used as hybridization probes, primers for automated DNA sequencing, research tools for the studies on structure and dynamics of nucleic acids and proteiss, etc. [1-3]. Cyanine dyes have excellent properties of the most sensitive nucleic acid fluorescence probes currently available. They have large extinction coefficients (about $10^{5}$ $\mathrm{M}^{-1} \mathrm{~cm}^{-1}$ ), fluorescence covering a wide spectral range $(500-750 \mathrm{~nm})$, and high nucleic acid binding constants $[3]$.

Monomethyne benzothiazole and -oxazole cyanines are most suitable to develop new homogeneous detection systems for nucleic acids [4]. These dyes are nonfluorescent in free state beconing strongly fluorescent when bound to nucleic acids $>1000$-fold fluorescence increase) $[5,6]$. No separation of the excess of fluorescent probe is therefore essential for the detection based on this principle.

Recently, Pitner et al. [7] reported on covalent monomethyne cyanine dye-oligonucleotide conjugates for the detection of specific DNA sequences. $\mathrm{N}$ Hydroxysuccinimide ester of Thiazole Orange (TO) dye was used for the conjugation of cyanine with 5 '-end amino-modified oligonucleotides [7]. Before some synthetic procedures for the covalent labelling of biomolecules with cyanine dyes werc described. Functional groups in proposed cyanine reagents were sulfhydryl [8], isotiocyanate [9] and succinimidyl esters $[10]$.

In this paper we propose a new efficient procedure for the fluorescent labelling of oligonucleotides with cyanine dyes.

Materials and Methods. Oligonucleotide synthesis was performed on Applied Biosystems Model 380B DNA synthesizer by standard phosphoramidite method using reagents and solvents from Milligen/Biosearch (USA). 5'-Aminoalkyl linker was introduced by reaction of $5^{\prime}$-deblocked oligonucleotide on polymer support with carbonyldiimidazole followed by hexamethylenediamine, according to $[11]$. Functionalized oligonucleotides were purified by electrophoresis in $20 \%$ denaturing polyacrylamide gel.

Reverse phase HPLC was carried out on Beckman «Gold System» chromatograph using Uitraprep $\mathrm{C}_{18}$ $(21 \times 1.5 \mathrm{~cm}$, «Beckman», USA) column with a linear gradient of acetonitrile $(0-30 \%)$ in $0.1 \mathrm{M}$ TEAB buffer $(\mathrm{pH} 6.5$ ) at flow rate $1 \mathrm{ml} / \mathrm{min}$.

Spectroscopic measurements. The absorption 
spectra were recorded on «Specord UV-VIS» spectrophotometer («Karl Zeiss Jena», Germany). Fluorescence spectra were obtained with fluorescence spectropholometer Hitachi Model 850 (Japan). Fluorescence was excited with $150 \mathrm{~W}$ Xe-lamp emission and measurements were carried out in thermostatable quartz cell $(0.5 \times 0.5 \mathrm{~cm})$. All spectra were corrected by multiplying fluorescence intensities measured over an interval of $5 \mathrm{~nm}$ by proper correction factor for corresponding wavelengths. In corrected spectra fluorescence intensity values were proportional to a numbers of photons per unit of wavelength interval.

The dye-oligonucleotide/polynucleotide complexes were prepared by adding 10-fold excess of polynucleotides to $3 \cdot 10^{-6} \mathrm{M}$ dye conjugate in TE buffer (10 mM Tris- $\mathrm{HCl}, 0.5 \mathrm{mM}$ EDTA, pH 7). Working solutions were then heated to $60{ }^{\circ} \mathrm{C}$ and equilibrated at $20^{\circ} \mathrm{C}$ for at least $24 \mathrm{~h}$. Extinction coefficient of $T_{15}$ at $260 \mathrm{~nm}$ calculated according to [16] was $1.22 \cdot 10^{5} \mathrm{M}^{-1} \mathrm{~cm}^{-1}$.

Genaral procedure for oligonucleotide 5 -labelling. $5^{\prime}-\mathrm{NH} 2-\left(\mathrm{CH}_{2}\right)_{6}-\mathrm{NH}-\mathrm{COO}-(\mathrm{T} p)_{14} \mathrm{~T} \quad\left(5 \mathrm{OD}_{260}, 40 \mu \mathrm{mol}\right)$ was dissolved in $60 \mu 1$ of $0.1 \mathrm{M} \mathrm{NaHCO}-\mathrm{Na}_{2} \mathrm{CO}_{3}$

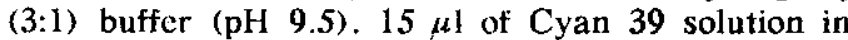
DMSO $(10 \mathrm{mmol} / \mathrm{ml}, 150 \mathrm{nmol})$ was added to oligonucleotide with agitation. 'The reaction mixture was incubated at $50{ }^{\circ} \mathrm{C}$ for $12 \mathrm{~h}$ in the dark. The progress of reaction was monitored by HPLC. Oligonucleotide material was precipitated by $2 \% \mathrm{LiClO}_{4}$ in acetone and 5 -labelled oligonucleotide was isolated by reverse phase HPLC. Yield of purified conjugate was $3.1 \mathrm{OD}_{200}(62 \%)$. Structure and purity of product were confirmed by spectroscopic measurements, HPLC and PAGE.

Results and Discussion. Fluorescent reporter groups can be covalently attached to oligonucleotides by a wide variety of methods $[1-3,12,13]$. The most popular of them are based on the reaction of $5^{\prime}$ aminoalkyl oligonucleotides with reagents bearing amine-specific reactive groups, usually isothiocyanate or $\mathrm{N}$-hydroxysuccinimide dye derivatives. We have found a new approach to oligonucleotide labelling utilizing pyrylium cyanine dyes.

Some new fluorescent cyanine dyes for nucleic acid staining have been recently proposed in our laboratory. Monomethyne cyanine dye Cyan 40 $\left({ }^{\mathrm{abs}} \lambda_{\max } 434 \mathrm{~nm},{ }^{\mathrm{em}} \lambda_{\max } 475 \mathrm{~nm}\right)$ has characteristics of suitable fluorescent dye for the quantification of nucleic acids: 1) low intrinsic fluorescence, 2) great fluorescence enhancement upon binding of dye to nucleic acids and 3) high fluorescence quantum yield for nucleic acid-dye complexes. At the same time, monomethyne pyrylium cyanine dye Cyan $39\left(^{\mathrm{abs}} \lambda_{\max }\right.$ $470 \mathrm{~nm},{ }^{2 \mathrm{~m}} \lambda_{\max } 490 \mathrm{~nm}$ ) has structure like Cyan 40 , but low fluorescence intensity upon binding to nucleic acids [14] (Fig. 1).

Pyrylium salts are known to react with primary amines giving corresponding pyridinium cations via formal $\mathrm{O}-\mathrm{N}$ substitution [15]. Thus, in the reaction of 5 '-aminoalkyl functionalized oligonucleotide with pyrylium cation oligonucleotide labelling could be achieved with simultaneous conversion of pyrylium dye into fluorescent pyridinium one. Proposed labelling procedure allows to prepare oligonucleotides modified with pyridinium dye Cyan 40 starting from pyrylium heterocycle of Cyan 39 (Fig. 2). In our approach fluorescent oligonucleotide probe is obtained from non-fluorescent predecessor. From this point of view, some analogy can be found in the labelling of biomolecules with non-fluorescent bromobimane transforming into fluorescent residue after reaction with thiol or thiophosphate group [3].

One of the main problems was that pyridinium cations like Cyan 40 are susceptible to nucleophilic

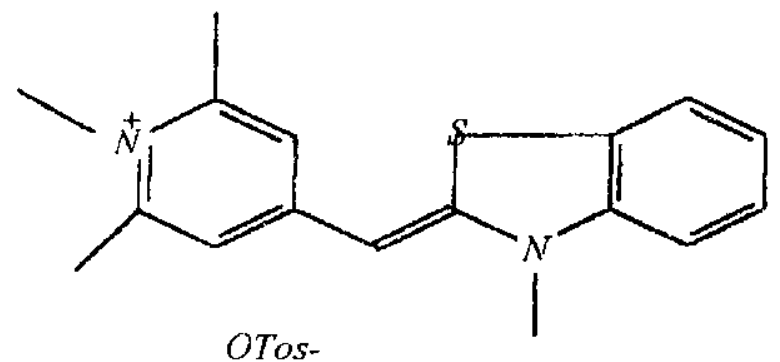

Cyan 40

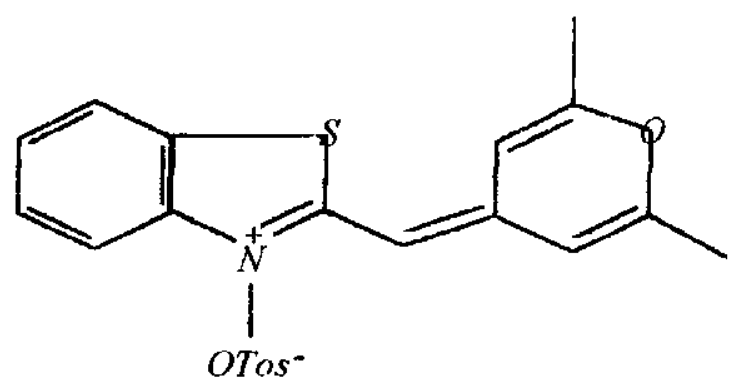

Cyan 39

Fig. 1. The chemical structure of cyanine dyes 
<smiles>CCCCNC(=O)O[Na]</smiles>

Fig. 2. Synthetic scheme of fluorescent labelling of oligonucleotides with pyrylium cyanine dye Cyan 39

displacement of the $\mathrm{N}$-substituent [15]. Therefore, the labclling conditions should have been carefully selected, since basic pH was essential for the reaction of aminoalkyl group with pyrylium cation, whereas at higher $\mathrm{pH}$ the alkaline hydrolysis of coupling product was observed as important yield-decreasing side reaction. We have found optimum labelling conditions in model reaction of Cyan 39 with aminocaproic acid which were then used for oligonucleotides. 5'-Aminohexyl pentadecathymidylate was prepared by introducing aminoalkyl linker group into oligonucleotide during solid phase synthesis by carbonyldiimidazole method [11]. The highest yield of functionalized oligonucleotide labelling with Cyan 39 was achieved for the reaction in $0.1 \mathrm{M}$ sodium bicarbonatc/carbonate buffer $(\mathrm{pH} 9.5)$. With equitnolar amount of reagents the completion of model reaction could be determined by UV-Vis spectra which showed that as the reaction progressed the absorption maximum of Cyan $39(470 \mathrm{~nm})$ declined almost to zero and the absorption at $434 \mathrm{~nm}$ increased correspondingly. But since the excess of dye (ca. 10 eq.) was used to increase the overall yield of oligonucleotide conjugate, the labelling reaction had to be monitored by HPLC.

It should be noted that in Dye- $T_{\text {is }}$ conjugate dye absorption maximum was shifted from 434 to $446 \mathrm{~nm}$ duc to the interaction of cyanine residue with oligonucleotide. The same effect was observed for the interaction of free Cyan 40 with nucleic acids in the solution $|14|$. UV/Vis spectrum of conjugate clearly confirmed the presence of cyanine dye residue by specific absorbance at $446 \mathrm{~nm}$. Detailed study of spectro-fluorescent properites of conjugates will be published elsewhere.

It the end of reaction oligonucleotide material was precipitated by $2 \% \mathrm{LiClO}_{4}$ in acetone and chromatographed on $\mathrm{C}_{18}$ reverse phase column with yield about $60 \%$ (Fig. 3). Purified oligonucleotide conjugate was shown to be homogeneous by both HPLC and PAGE. In the reverse phase chroma- tography, the conjugate had higher retention time than starting oligonucleotide due to the hydrophobic character of dye residue. The labelled oligonucleotide migrated in the polyacrylamide gel slower than nonmodified oligomer and was easily identified by its greenish fluorescence under long wavelength $(365$ nm) UV light. UV/Vis spectrum of conjugate clearly confirmed the presence of cyanine dye residue by specific absorbance at $446 \mathrm{~nm}$.

Cyan 40-labelled oligonucleotides could be used as hybridization probes for the detection of nucleic

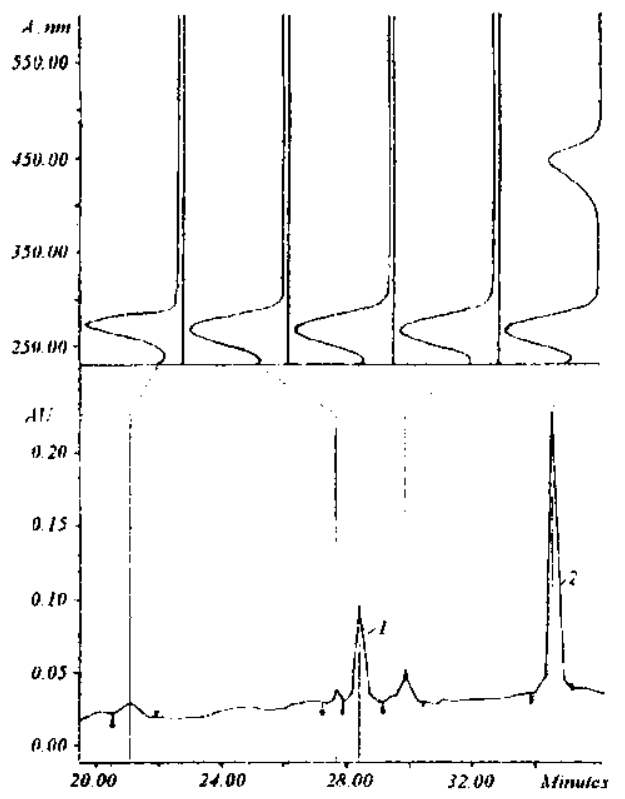

Fig. 3. HPLC profiles of reaction mixture of oligonucleotide labelling with Cyan 39 and absorbance spectra of components: $I-5^{\prime}-\mathrm{NH}_{2}$ $\left(\mathrm{CH}_{2}\right)_{6}-\mathrm{NH}-\mathrm{COO}-(\mathrm{Tp}) 141^{\prime} ; 2-5^{\prime}-\mathrm{Dye}-\left(\mathrm{CH}_{2}\right)_{6}-\mathrm{NH}-\mathrm{COO}$ (Tp) ${ }_{[4} \mathrm{T}\left({ }^{\mathrm{abs}} \lambda_{\max } 446 \mathrm{~nm}\right)$ 
acids by common techniques. At the same time, the preliminary experiments to study the changes of fluorescence upon interaction of labelled oligonucleotide with complementary nucleic acids in the solution were also carried out using the simplest model systems. The fluorescence of $T_{15}$-Cyan 40 probe was measured before and after hybridization to the complementary poly (rA) and poly (dA) chains. After the formation of duplexes the fluorescence emission at $475 \mathrm{~nm}$ increased 1.9 and 2.1 times, respectively (Fig. 4). This increase of fluorescence for dye conjugate was much lower than could be observed for the interaction of free Cyan 40 with double-stranded nucleic acids [14].

The obtained data are in full agreement with Pitncr's results for TO-oligonucleotide conjugates demonstrated that the fluorescence of resulting probetarget double-stranded complexes increased 3.5-5fold in comparison with that of single-stranded $T O$ conjugate before hybridization [7], whereas the increase of fluorescence of non-conjugated TO upon interaction with double-stranded nucleic acids was 3 orders of magnitude higher $[6,7]$. At least two hypothesis can be presented to explain the insignificant increase in fluorescence of Cyan 40 (or Thiazole Orange) when it was conjugated to ojigonucleotide. The first explanation would be that the ratio of 1 dye per 15 b. p. upon formaîion of duplex is insufficient to reach a maximum of fluorescence emission observed at the ratio $1 \mathrm{dyc} / 2 \mathrm{~b}$. p. for Cyan 40 [14]. Then, it is possible that conjugated dye does not intercalate into formed oligonucleotjde-target duplex, probably due to some steric factors, and simply «sticks» to the end nucleotides as cationic molecule. In this case, the choice of appropriate linker construction could allow the efficient intercalation. Studies

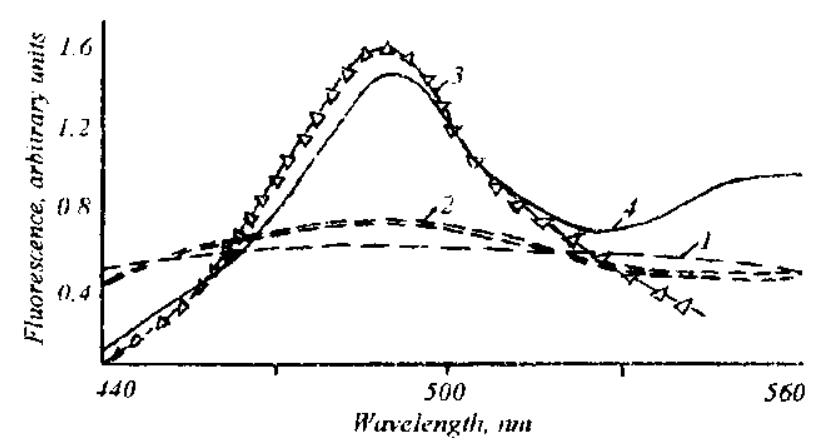

Fig. 4. Hluorescence spectra of free Cyan 40: $1-5^{\prime}-$ Dye- $\left(\mathrm{CH}_{2}\right)_{0}$ $\mathrm{NH}-\mathrm{COO}$-( $\mathrm{Tp})_{14} \mathrm{~T} ; 2$ - and duplexes of oligonucleotide-dye conjugate with poly (dA) (3) and poly(rA) (4) of these problems on various model systems are in progress.

Thus, we propose a new oligonucleotide labelling system that does not require any preparation of active intermediates as a convenient, efficient and flexible alternative for known methods of nucleic acids labelling and detection. This method also seems to be perspective for the development of homogeneous detection systems for nucleic acids.

Acknowledgement. The authors gratefully acknowledge the assistance of Ms. Vladislava Kovalska in spectral characterization of dye-oligonucleotide conjugates. We thank Dr. Yury Kovtun for providing us with the sample of cyanine dye Cyan 39.

С. М. Ярмолюк, О. М. Костенко, О. С. Корнкиина, І. Я. Дубей

Взаемодія ціанінових барвників з нуклеїновими кислютами. 4. Ефектияне $5^{\prime}$-флюоресцентне мічення олігонуклеотидіз монометиновим пірилієвим барвником Суап 39

Резюме

Запропоновано новий підхід для флюоресцентного мічення олігонуклеотидіз монометиновими пірилісвими барвниками. реакція пірилісвих солей з первиниими аміноми була використана для кон'югації ціанінових барвникіо 3 5'-алкіламіноолігонуклеотидами $і$ перетворення нефлюоресцентносо пірилієвого барвника у флюоресцентний піридинісвий - Cуап 40.

\section{С. Н. Ярмолюк, О. М. Костенко, О. С. Корнипани,} И. Я. Дубей

Взаимодейсгвие цианиновых красителей с нуклеиновыми кислотами. 4. Эффективнос 5'-флюоресцентное мечение олигонуклсотидов монометиновым пирилиевым красителем Cуan 39

Резюме

Предложен новый подход для флюоресцентного меления олигоиуклеотидов монометиновыми пирилиевыми красителями. Реакция пирилиевьх солей с первинными аминами была использована для конбюгации цианиновых красителей с 5'-алкиламиноолигонуклеотидами и превращения иефлкоресцентного пирилиевого красителя во флюоресцентный пиридиниевый Cyan 40.

\section{REFERENCES}

1. English $U$., Gauss D. H. Chemically modified oligonucleotides as probes and inhibitors // Angew. Chem. Int. Ed. Engl.1991.-30.--P. 613-629.

2. DNA Probes / Eds G. H. Keller. M. Manak.-New York: MacMillan press, 1993.--656 p.

3. Haughland $R$. P. Handbook of fluorescent probes and research chemicals // Molecular Probes.-Eugene: OR, 1996.-679 p.

4. Schwirtz H. E., Ulfelder K.J. // Anal. Chem.-1992.-64.P. $1737-1740$.

5. Lee G. L., Chen C.-H, Chiu I. A. Thiazole Orange: a new dye for reliculocyte analysis // Cytometry.-1986.-7.P. 508--517.

6. Rye H. S., Quesada M. A., Peck $K$. et al. High-sensitive two-color detection of double-stranded DNA with a confocal 
fluorescence gel scanner using ethidium homodimer and thia zole orange // Nucl Acids Res, - 1991.-19._. P. 327-333.

7. Pitner J. B., Mize P. D. Linn C. P. Synthesis and fluorescence properties of covalent thiazole oraige-oligonucleotide conjugates // The 3rd Int. Symp. on Functional Dyes (July 16-21, 1995).--Santa Cruz, 1995.--P. 52

8. Ernst L. A., Cupta R. K., Mujumdar R. B. et al. Cyanine dye labeling reagents for sulfhydryl groups // Cytometry.1989.-10.--P. 3-10.

9. Mujumdar R. B., Ernst L. A., Mujumdar S. R. et al. Cyanine dye labeling reagents containing isothiocyanate groups // Ibid.-1989. - 10.-P. $11-19$

10. Southwick P. L., Ernst L. A., Tawiello E. W. et al. Cyanine dye labeling reagents - carboxymethylindocyanine succinimidyl esters // Jbid.-1990.--11.-. P. 418--430.

11. Wachter L., Jablonski J., Ramachandran $X . L$ A simple and efficient procedure for the synthesis of $5^{\prime}$-aminoalkyl oligonucleotides // Nucl. Acids Res. -1986 . -14.-p. 7985-7994.
12. Goodchild J. Conjugates of oligonucleotides and modified oligonucleotides: a revicw of their synthesis and properties // Bioconjugate Chem.-1990.-1 - P. 165-187.

13. Protocols for oligonucleotide conjugates // Meth. Mol. Biol.New York: Humana press, 1994.-377 p.

14. Yarmoluk S. M. Kovalske V. B., Kovtun Yu. P. Interaction of cyanine dyes with nucleic acids. 5. Towards model of «Half interaction* of monomethyne cyanine dyes into double-stranded nucleic acids $/ /$ Biopolymers and Cell.-1998.-14, N 5.- (in press)

15. Katritzky A. R. Conversions of primary amino groups into other functionality mediated by pyrylium cations // Tetrahedron.1980.-36.-P. 679-690.

16. Handbook of biochemistry and molecular biology / Ed. G. Fasman.-Boca Raton: CRC, 1975.-P. 175.

Received 05.05.97 